\title{
Influence of pre-eruptive degassing and crystallization on the juvenile products of laterally directed volcanic explosions
}

\author{
Owen K. Neill ${ }^{\mathrm{a}, \mathrm{b}, *}$, Julia E. Hammer ${ }^{\mathrm{a}}$, Pavel E. Izbekov ${ }^{\mathrm{b}}$, Marina G. Belousova ${ }^{\mathrm{c}, \mathrm{d}}$, Alexander B. Belousov ${ }^{\mathrm{c}}$, \\ Amanda B. Clarke ${ }^{\mathrm{e}}$, Barry Voight ${ }^{\mathrm{f}}$
}

a Department of Geology E Geophysics, University of Hawaii - Manoa, 1680 East West Road, Honolulu, HI, USA, 96822

b Geophysical Institute, University of Alaska Fairbanks, 903 Koyukuk Drive, Fairbanks, AK, USA, 99775-7320

c Earth Observatory of Singapore, Nanyang Technological University, 50 Nanyang Avenue, Block N2-01a-15, Singapore 639798

d Institute of Volcanology and Seismology, Piip \#9, Petropavlovsk-Kamchatsky, Russia 683006

e School of Earth and Space Exploration, Arizona State University, P.O. Box 871404, Tempe, AZ, USA, 85287-1404

${ }^{\mathrm{f}}$ College of Earth and Mineral Sciences, Pennsylvania State University, University Park, PA, USA, 16802

\section{A R T I C L E I N F O}

\section{Article history:}

Received 5 March 2010

Accepted 3 September 2010

Available online 17 September 2010

\section{Keywords:}

cryptodome

directed blast

bubble growth

Mount St. Helens

Bezymianny

\begin{abstract}
A B S T R A C T
Strikingly similar examples of edifice collapse and directed blast are the 18 May 1980 eruption of Mount St. Helens (MSH), Washington, USA, and the 30 March 1956 eruption of Bezymianny Volcano (BZ), Kamchatka, Russia. In these cases, flank failures led to near-instantaneous decompression and fragmentation of intra-edifice cryptodome magma, which produced catastrophic, laterally directed blasts. In both instances, the blast products consisted of juvenile material with bimodal density/vesicularity distributions: low- and high-density modes at 1900 and $2400 \mathrm{~kg} \mathrm{~m}^{-3}$ for BZ, 1600 and $2300 \mathrm{~kg} \mathrm{~m}^{-3}$ for MSH, although the proportion of high-density material is greater at BZ. Blast materials also exhibit striking variety in groundmass crystallinity ( $<40$ to $>90$ vol.\%) despite having fairly uniform pheno-crystallinities, suggesting that degassing-driven groundmass crystallization occurred to varying extents within cryptodome magma at both volcanoes. New bulk-rock $\mathrm{H}_{2} \mathrm{O}$ and $\partial \mathrm{D}$ measurements confirm that progressive open-system outgassing occurred prior to both blasts. The correlations between crystallinity, clast density, and bulk $\mathrm{H}_{2} \mathrm{O}$ contents suggest that syn-blast magma expansion was modulated both by non-uniform volatile distribution within the cryptodome and rheological controls associated with non-uniform crystal content. Spatial heterogeneities in volatiles and crystallinity within a given cryptodome are attributed to distance from the wallrock margin, which probably correlates with timing of magma injection. The greater proportion of high-density material at BZ is speculatively related to lower blast energy compared with MSH.
\end{abstract}

(C) 2010 Elsevier B.V. All rights reserved.

\section{Introduction}

The similarities between the 30 March 1956 eruption of Bezymianny Volcano (abbreviated hereafter as BZ), Kamchatka, Russia, and the 18 May 1980 eruption of Mount St. Helens (MSH) in Washington, USA have been noted by numerous authors (Lipman et al., 1981; Voight et al., 1981; Cashman and Taggart, 1983; Bogoyavlenskaya et al., 1985; Crandell and Hoblitt, 1986; Belousov, 1996; Belousov et al., 2007). Each eruptive sequence began with pronounced deformation of the volcanic edifice related to the emplacement of a shallow cryptodome, lasting 2 months at MSH and 4-6 months at BZ (Gorshkov, 1959; Lipman et al., 1981). The cryptodome-related deformation eventually destabilized the flank of each edifice, leading to edifice collapse and a subsequent

\footnotetext{
* Corresponding author. Present address: Geophysical Institute, University of Alaska Fairbanks, 903 Koyukuk Drive, Fairbanks, AK, 99775-7320, USA. Tel.: + 19074746171.

E-mail addresses: owen@gi.alaska.edu (O.K. Neill), jhammer@soest.hawaii.edu (J.E. Hammer), pavel@gi.alaska.edu (P.E. Izbekov), belousov@mail.ru (M.G. Belousova, A.B. Belousov), amanda.clarke@asu.edu (A.B. Clarke), voight@ems.psu.edu (B. Voight).
}

directed blast (Voight, 1981; Voight et al., 1981; Belousov and Bogoyavlenskaya, 1988), distributed over an area of $500 \mathrm{~km}^{2}$ at BZ and $600 \mathrm{~km}^{2}$ at MSH (Hoblitt et al., 1981; Moore et al., 1981; Belousov, 1996). Pyroclasts at both BZ and MSH are bimodally distributed with respect to density and vesicularity (Hoblitt and Harmon, 1993; Belousov, 1996). A climactic eruption, including both pyroclastic density currents and an eruption column $>20 \mathrm{~km}$ in height followed each blast (Christiansen and Peterson, 1981; Belousov, 1996), and dome growth subsequently occurred within the collapse crater (Alidibirov et al., 1990; Cashman, 1992; Pallister et al., 2008).

Differences in the density and vesicularity distributions of a pyroclastic deposit can result from contrasting syn-explosive fragmentation processes (e.g. Gurioli et al., 2005; Adams et al., 2006). Consequently, a better understanding of cryptodome fragmentation may be achieved through study of pre-explosive outgassing and crystallization processes preserved in blast materials. This study examines and compares volatile distributions and crystallization conditions within the cryptodomes at BZ and MSH prior to the directed blasts, and investigates the effects of these conditions on the density distributions of blast pyroclasts. 


\subsection{Mechanisms and products of directed blasts}

The term "directed blast," first coined by Gorshkov (1959) in describing the $1956 \mathrm{BZ}$ eruption, refers to a large, highly destructive, laterally directed volcanic explosion or series of explosions, resulting in a pyroclastic density current (Hoblitt, 2000; Belousov et al., 2007; Voight et al., 2009). Directed volcanic blasts result from the fragmentation of a shallow gas-pressured magma body, the emplacement of which destabilizes the volcanic edifice (Gorshkov, 1959, 1963; Lipman et al., 1981; Voight, 1981; Voight et al., 1981; Belousov and Bogoyavlenskaya, 1988; Belousov, 1996; Belousov et al., 2007). The loss of confining pressure during an edifice collapse allows rapid growth of pressurized bubbles, and fragmentation, driven by the release of the gas pressure (Alidibirov and Dingwell, 1996). The bubbles originated from volatiles released by magmatic degassing during ascent and emplacement (Alidibirov, 1995; Navon et al., 1998). Syn-eruptive diffusion of volatiles into bubbles may also occur, as suggested by breadcrust bombs with low $\left(\sim 1200 \mathrm{~kg} / \mathrm{m}^{3}\right)$ internal densities (Hoblitt et al., 1981; Alidibirov et al., 1997).

While flank failure can trigger eruptions of various types, the highenergy directed blasts seen at BZ and MSH cannot be generated without a volatile-rich, shallow magma body (Belousov et al., 2007). For example, the 1964 eruption of Shiveluch in Kamchatka, and the 1933 eruption of Harimkotan in the Kurile Islands, included flank collapses that were followed by Plinian eruptions with no directed blast in between (Belousov et al., 2007). Other recent directed blasts have been reported at Soufrière Hills Volcano, Montserrat (Ritchie et al., 2002) and Augustine, Alaska (Siebert et al., 1995). Comparative studies of the BZ and MSH blasts, as well as with other similar eruptions (e.g. Bogoyavlenskaya et al., 1985; Belousov et al., 2007) can help determine which features of directed blasts are ubiquitous, and which are unique to individual eruptions.

The range in vesicularity among clasts at BZ and MSH confers distinctions in coloration, with the dense clasts clearly darker. Thus in early studies at MSH, such dense clasts were dismissed as accidental until Hoblitt and Harmon (1993) demonstrated that they were indeed juvenile. Whereas the MSH clasts span a continuous spectrum with respect to density and vesicularity, the frequencies of dense and vesicular clasts are bimodally distributed (Fig. 1). Thus Hoblitt and Harmon (1993) divided the two density modes of the blast dacite at MSH into "black" and "grey" categories, with black corresponding to the dense clasts and grey the more vesicular, with a separation at about $2000 \mathrm{~kg} / \mathrm{m}^{3}$. Blast deposits at BZ also are bimodally distributed (Fig. 1; Belousov, 1996; Belousov et al., 2007), although here the highdensity clasts contribute $\sim 65$ vol.\% of the deposit, compared to $28 \mathrm{vol}$. $\%$ at MSH (Hoblitt and Harmon, 1993; Belousov et al., 2007). The same cutoff value of $2000 \mathrm{~kg} / \mathrm{m}^{3}$ is used herein to differentiate the dense and vesicular material from both MSH and BZ blast deposits. However, "low density" and "high density" are employed, because density - not color - is the primary criterion distinguishing the two populations.

\subsection{Volatile loss, crystallization and fragmentation of cryptodomes}

Silicic dome lavas are outgassed relative to magma in crustal storage reservoirs, primarily because of the dependence of volatile solubility on confining pressure (e.g. Moore et al., 1998). Moreover, $\mathrm{H}_{2} \mathrm{O}$ loss increases magma liquidus temperature and creates an effective undercooling that drives crystallization (Westrich et al.,
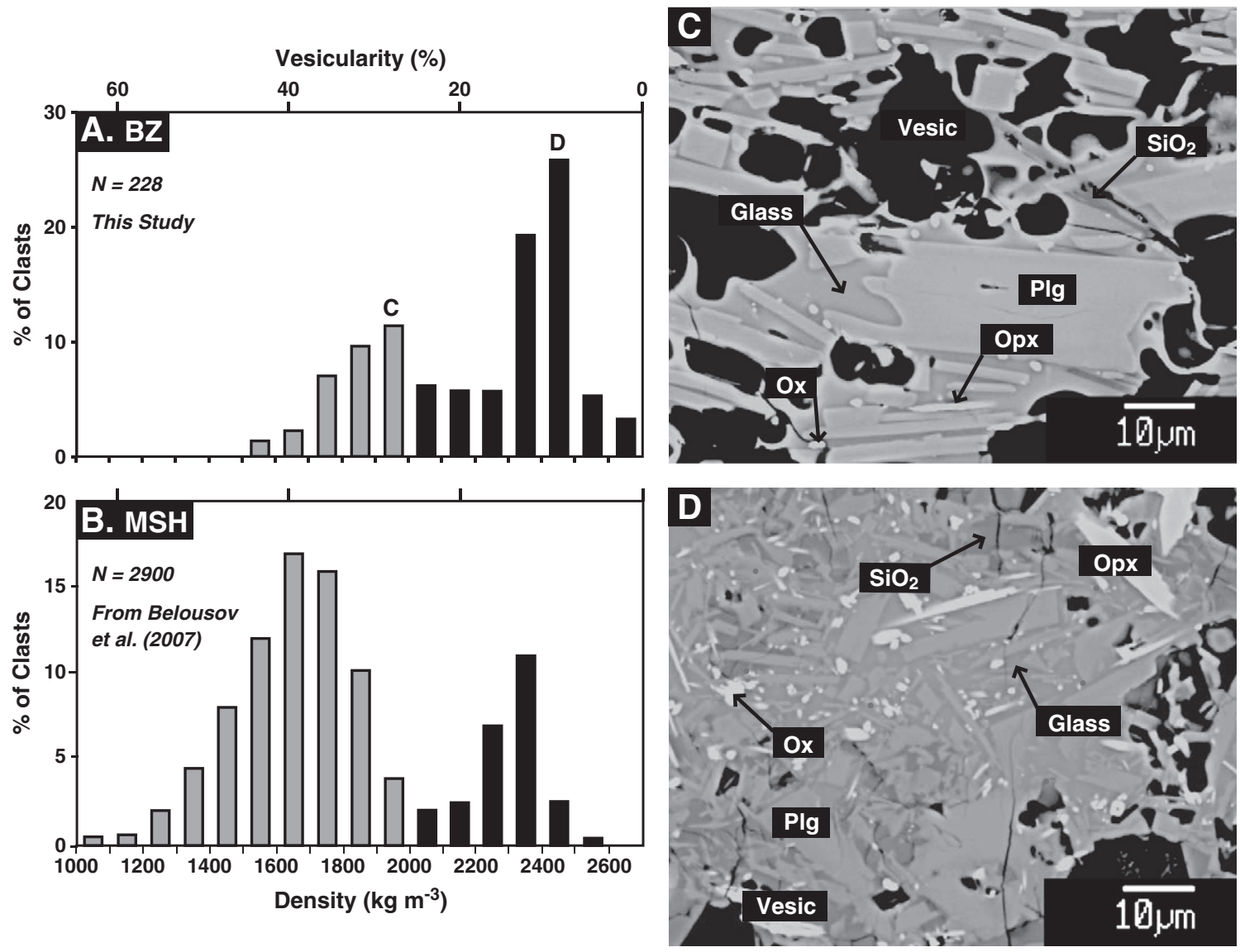

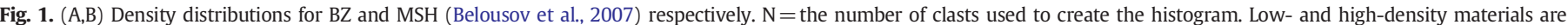

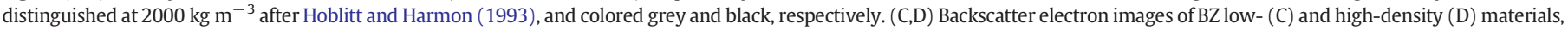

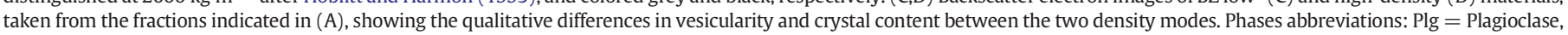
$\mathrm{OPX}=$ Orthopyroxene, $\mathrm{SiO}_{2}=$ Quartz, $\mathrm{Ox}=\mathrm{Fe}-\mathrm{Ti}$ Oxides, Vesic $=$ Vesicle. 
1988; Swanson et al., 1989; Geschwind and Rutherford, 1995; Hammer and Rutherford, 2002), as has been inferred for domes at MSH (Cashman, 1992; Blundy and Cashman, 2001), Unzen (Nakada and Motomura, 1999) and Merapi (Hammer et al., 2000).

The style and history of magma outgassing influences how bubbles within a melt expand during explosive fragmentation, and ultimately controls the post-eruptive clast densities and vesicularities. Hoblitt and Harmon (1993) concluded that heterogeneous volatile loss through the permeable margins of the MSH cryptodome was the cause of the bimodal clast density distributions, whereby the magma destined to become the high-density material had lost sufficient volatiles during ascent and storage within the cryptodome to prevent syn-blast vesiculation. This conclusion was supported by Alidibirov et al. (1997), who suggested that the heterogeneous outgassing prior to fragmentation led to a heterogeneous distribution of bubbles within the MSH cryptodome prior to fragmentation, and that this variation in vesicularity was preserved upon fragmentation. Thus the material that remained dense was volatile-poor prior to the blast, and experienced no syn-blast bubble growth, while material that expanded fragmented the cryptodome. Crystallization, and specifically changes in crystal content, can also exert control on vesiculation. Klug and Cashman (1994) demonstrated that increased pre-fragmentation microlite contents restricted bubble growth in MSH grey pumice to a degree not seen in the relatively crystal-poor white pumice.

While the high groundmass crystallinity and pervasive cracking of both BZ and MSH blast material precludes the study of vesicle textures to understand syn-fragmentation vesiculation processes (e.g. Adams et al., 2006), the solid phases in the blast products remain sufficiently pristine to enable investigation of volatile and crystallization conditions within the BZ cryptodome and allow these conditions to be compared to both new and previously published estimates of these conditions at MSH. Therefore, the specific goals for this study are to compare the pre-blast outgassing at $\mathrm{BZ}$ to the better-established models for MSH; to investigate the effects of degassing (transfer of volatile species from melt to bubbles) and outgassing (the transfer of volatiles from the magma body to the external ambient environment) on the bulk and groundmass crystallinity and phase compositions at both $\mathrm{BZ}$ and $\mathrm{MSH}$; to evaluate the effects of pre-blast outgassing and crystallization on bubble expansion during fragmentation, in light of existing models; and to investigate the effects that outgassing and crystallization have on the post-eruptive clast density distributions.

\section{Methods}

\subsection{Sampling and density/vesicularity measurements}

BZ blast products were sampled in 2008 from two locations to the southwest of Bezymianny Volcano (Fig. 2). At least 110 juvenile clasts from 16 to $32 \mathrm{~mm}$ were sampled at each location. Clast density and vesicularity were calculated using the method of Houghton and Wilson (1989), using silicone spray as a waterproofing medium and assuming a dense-rock equivalent (DRE) value of $2700 \mathrm{~kg} / \mathrm{m}^{3}$ for both MSH and BZ (Hoblitt and Harmon, 1993; Belousov et al., 2007). Seven MSH clasts were taken from the sample set of Belousov et al. (2007, locations shown in Fig. 2). At both MSH and BZ, only juvenile material was sampled; accidental clasts were discarded. Representative clasts from each sample suite were chosen for bulk $\mathrm{H}_{2} \mathrm{O}$ analysis, representing modal, minimum, maximum and intermediate density values (Fig. 1). Clasts were also selected for standard petrographic analysis of phase proportions and compositional analysis of glass and feldspar.

\subsection{Electron microprobe analysis}

All analyses of phase compositions were performed on the JEOL JXA8500F Field Emission Hyperprobe at the University of Hawaii - Manoa,

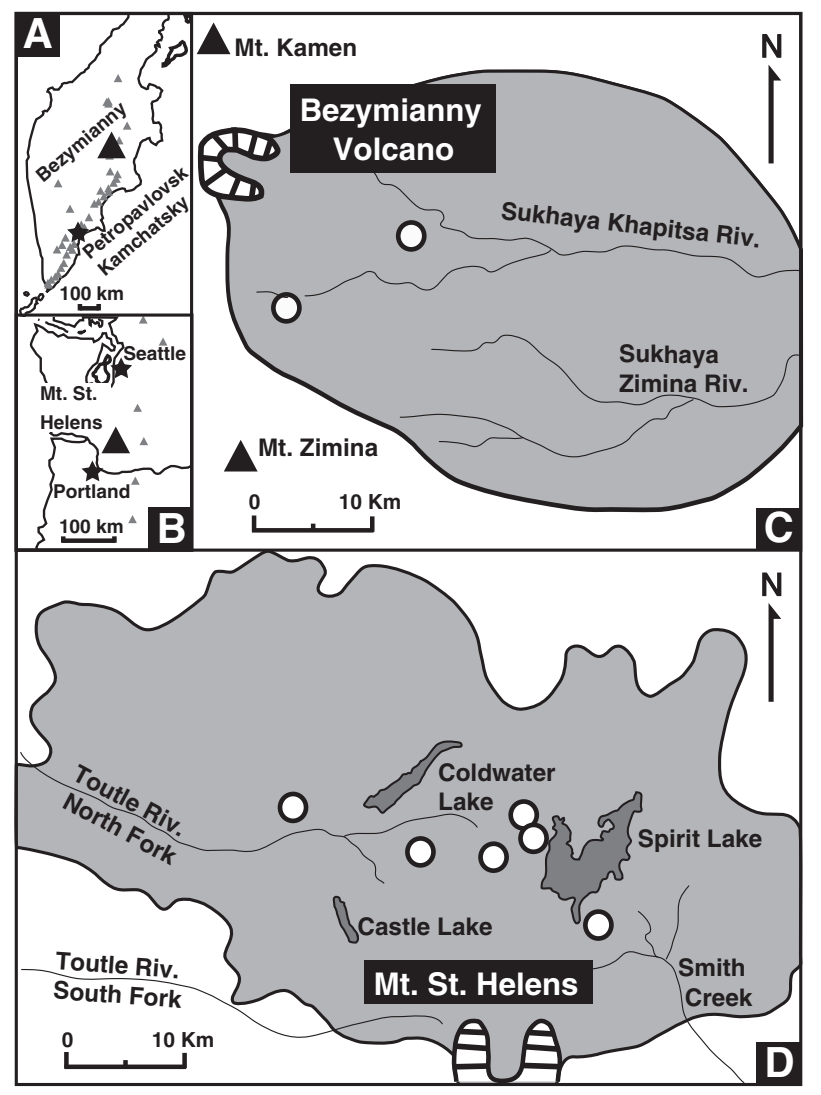

Fig. 2. (A,B) General location maps for BZ and MSH volcanoes, respectively. Grey triangles represent other Holocene volcanoes from the same respective arc systems. (C,D) Locations of sample sites with selected local landmarks at BZ and MSH, respectively. Black-bordered circles represent sample locations. Light grey shaded areas represent the distribution of directed blast material at BZ (after Belousov, 1996) and MSH (after Hoblitt et al., 1981).

using a $15 \mathrm{keV}$ electron beam and beam current of $10 \mu \mathrm{A}(15 \mu \mathrm{A}$ for plagioclase). Na- and K-loss as well as Si "grow in" (Morgan and London, 1996) were corrected using Time-Dependant Intensity (TDI) corrections incorporated in ProbeForWindows software (Donovan et al., 2007), and by analyzing $\mathrm{Si}$, Na and $\mathrm{K}$ first. Concentrations were obtained from raw counts using a ZAF intensity correction. Samples were chosen from across a range of densities in order to evaluate differences in phase chemistry among clasts of differing bulk density and crystallinity. Further details of electron microprobe methodology are included in Appendix A.

\subsection{Bulk-rock $\mathrm{H}_{2} \mathrm{O}$ measurement}

Bulk $\mathrm{H}_{2} \mathrm{O}$ contents were obtained through Karl Fischer Titration (KFT) at the University of Alaska Fairbanks using a Mitsubishi coulometric moisture meter, model CA-06, v. 4.2, coupled with VA-21 vaporizer. Clasts were crushed to $\leq 200 \mu \mathrm{m}$ and pre-dried overnight at $110^{\circ} \mathrm{C}$ in a vacuum oven. $15-20 \mathrm{mg}$ of powder were then heated in the VA-2 1 for 15 min at $150^{\circ} \mathrm{C}$ to drive off any remaining adsorbed $\mathrm{H}_{2} \mathrm{O}$, and heated again at $1000{ }^{\circ} \mathrm{C}$ to release $\mathrm{H}_{2} \mathrm{O}$ from hydrous phases. Desiccated $\mathrm{N}_{2}$ gas carried the liberated $\mathrm{H}_{2} \mathrm{O}$ into the titration cell; the reaction between $\mathrm{H}_{2} \mathrm{O}$ and iodine, generated coulometrically in the titration cell, allowed for quantitative $\mathrm{H}_{2} \mathrm{O}$ measurement (Behrens, 1995; Kato, 1999). Raw analyses were corrected against frequent measurements of standard WW2 (Westrich, 1987, 0.324 wt.\% $\mathrm{H}_{2} \mathrm{O}$ ); these measurements were also used to calculate analytical uncertainty. Analyses were corrected for $\mathrm{H}_{2} \mathrm{O}$ unreleased from hydrous phases at $1000{ }^{\circ} \mathrm{C}$ (e.g. Behrens and Stuke, 2003); further details are included in Appendix B. 


\subsection{Manometry}

The deuterium/hydrogen ratio of a volcanic rock can reveal its preeruptive degassing history (e.g. Taylor, 1986). Amphibole $\mathrm{H}_{2} \mathrm{O}$ content and bulk-rock hydrogen isotopic content of a subset of BZ blast clasts were obtained by manometry at the Université de Lausanne. Because of the difficulties of accurately measuring $\mathrm{D} / \mathrm{H}$ ratios in samples with low bulk $\mathrm{H}_{2} \mathrm{O}(<0.15-0.2$ wt.\%, Dr. T.W. Venneman, pers. comm.) and possible kinetic effects on $\mathrm{D} / \mathrm{H}$ partitioning at low $\mathrm{H}_{2} \mathrm{O}$ contents leading to anomalous deuterium enrichment (Anderson and Fink, 1989), samples yielding $<0.25 \mathrm{wt} . \% \mathrm{H}_{2} \mathrm{O}$ were not included in interpretations. Samples were analyzed with a TC-EA coupled to a DeltaPlus XL isotope ratio mass spectrometer (IRMS). 5-10 mg of powdered sample $(\leq 120 \mu \mathrm{m})$ were dried at $150{ }^{\circ} \mathrm{C}$, then heated rapidly in flowing $\mathrm{He}$ gas to $1450{ }^{\circ} \mathrm{C}$, liberating $\mathrm{H}_{2}$ from $\mathrm{H}_{2} \mathrm{O}$. The flowing $\mathrm{He}$ gas carried the liberated $\mathrm{H}_{2}$ into the IRMS. Five $\mathrm{BZ}$ blast clasts were analyzed for hydrogen isotopes using the method of Sharp et al. (2001); amphibole $\mathrm{H}_{2} \mathrm{O}$ content was determined using the method of Vennemann and O'Neil (1993) on a separate from the MSH white pumice clast SH-084 (described by Rutherford et al., 1985).

\section{Results}

\subsection{Bulk-rock compositions}

Bulk-rock compositions, obtained by X-ray fluorescence (Appendix A), are the same for low- and high-density BZ blast materials (Table 1 ). As was the case at MSH (Hoblitt and Harmon, 1993), BZ low- and high-density materials are chemically indistinguishable not only from each other but also from post-blast juvenile pumice produced during later phases of the climactic eruption (Belousov, 1996; Ozerov et al., 1997), indicating that each of these components is derived from the same juvenile magma. Physical differences between the low- and high-density materials at BZ are thus interpreted as the result of post-formation crystallization and vesiculation processes - a finding that echoes Hoblitt and Harmon (1993) for MSH - rather than as the differences between separate magmas erupted simultaneously.

Table 1

Bulk XRF chemical analyses of BZ blast andesite. Oxides are in wt.\% with all $\mathrm{Fe}$ as $\mathrm{Fe}_{2} \mathrm{O}_{3}$ trace elements in ppm.

\begin{tabular}{|c|c|c|c|c|c|c|}
\hline Low/high density & LD & LD & LD & LD & HD & HD \\
\hline $\mathrm{SiO}_{2}$ & 60.5 & 61.1 & 60.3 & 60.7 & 61.0 & 61.0 \\
\hline $\mathrm{TiO}_{2}$ & 0.63 & 0.61 & 0.59 & 0.59 & 0.62 & 0.58 \\
\hline $\mathrm{Al}_{2} \mathrm{O}_{3}$ & 18.4 & 18.3 & 17.8 & 17.5 & 18.3 & 18.6 \\
\hline $\mathrm{Fe}_{2} \mathrm{O}_{3}^{*}$ & 6.77 & 6.68 & 6.46 & 6.48 & 6.82 & 6.55 \\
\hline $\mathrm{MnO}$ & 0.15 & 0.15 & 0.14 & 0.14 & 0.15 & 0.14 \\
\hline $\mathrm{MgO}$ & 2.73 & 2.50 & 2.75 & 2.71 & 2.65 & 2.38 \\
\hline $\mathrm{CaO}$ & 6.91 & 6.65 & 6.54 & 6.30 & 6.68 & 6.75 \\
\hline $\mathrm{Na}_{2} \mathrm{O}$ & 3.08 & 3.09 & 3.60 & 3.50 & 3.11 & 3.08 \\
\hline $\mathrm{K}_{2} \mathrm{O}$ & 1.22 & 1.26 & 1.30 & 1.32 & 1.25 & 1.24 \\
\hline $\mathrm{P}_{2} \mathrm{O}_{5}$ & 0.18 & 0.18 & 0.18 & 0.18 & 0.18 & 0.19 \\
\hline Total & 100.5 & 100.4 & 99.7 & 99.4 & 100.7 & 100.5 \\
\hline LOI & 0.26 & 0.30 & 0.25 & 0.41 & 0.01 & -0.04 \\
\hline Sc & 10 & 9 & 9 & 10 & 10 & 8 \\
\hline $\mathrm{V}$ & 76 & 62 & 61 & 65 & 69 & 63 \\
\hline Co & 8 & 7 & 8 & 7 & 8 & 7 \\
\hline $\mathrm{Ni}$ & 6 & 5 & 9 & 6 & 8 & 4 \\
\hline $\mathrm{Zn}$ & 72 & 71 & 66 & 66 & 71 & 71 \\
\hline $\mathrm{Rb}$ & 24 & 25 & 27 & 27 & 25 & 25 \\
\hline $\mathrm{Sr}$ & 354 & 355 & 354 & 340 & 353 & 365 \\
\hline $\mathrm{Y}$ & 20 & 20 & 19 & 20 & 19 & 19 \\
\hline $\mathrm{Zr}$ & 110 & 113 & 113 & 120 & 114 & 113 \\
\hline $\mathrm{Ba}$ & 265 & 275 & 295 & 294 & 271 & 273 \\
\hline $\mathrm{Pb}$ & 3 & 3 & 3 & 2 & 3 & 3 \\
\hline
\end{tabular}

\subsection{Phase proportions}

Phase modes for BZ and MSH blast material were determined from manual point counting of thin sections and backscatter electron images (Appendix A). Perhaps the most striking observation to be drawn from the phase proportions (Table A4-1) is the strong correlation between density and groundmass crystallinity, with dense material having significantly higher groundmass crystal content than less dense material (Fig. 3). As phenocryst populations are sub-equal in both BZ and MSH clasts (Table A4-1), the elevated groundmass crystal contents of the high-density material imply elevated bulk crystal contents (Fig. 3); only one high-density clast is less than $80 \%$ crystalline, while no low-density material exceeds $80 \%$. Also noteworthy is that one of the dense MSH clasts is holocrystalline.

\subsection{Bulk and glass $\mathrm{H}_{2} \mathrm{O}$ contents}

Analyses of BZ material (Fig. 4) indicate a somewhat similar result to the findings of Hoblitt and Harmon (1993) for MSH clasts, although the difference between high- and low-density material in terms of both bulk and glass $\mathrm{H}_{2} \mathrm{O}$ content seems less clear (Fig. 4). Using the method of Alidibirov et al. (1997), glass $\mathrm{H}_{2} \mathrm{O}$ contents can be estimated by mass balance, whereby the bulk $\mathrm{H}_{2} \mathrm{O}$ content of a clast is a function of the hydrous phases it contains:

$X_{W R}^{\mathrm{H}_{2} \mathrm{O}}=\left(X_{\mathrm{Hbl}}^{\mathrm{H}_{2} \mathrm{O} *} X_{W R}^{\mathrm{Hbl}}\right)+\left(X_{\text {Glass }}^{\mathrm{H}_{2} \mathrm{O}} * X_{W R}^{\text {Glass }}\right)$.

Hornblende ( $\mathrm{Hbl}$ ) and Glass are the hydrous phases, $X^{H B L}$ and $X^{\text {Glass }}$ are the weight fractions of that phase in the material of interest in the bulk rock (WR), and the $\mathrm{X}_{2} \mathrm{O}$ terms represent the weight fraction of

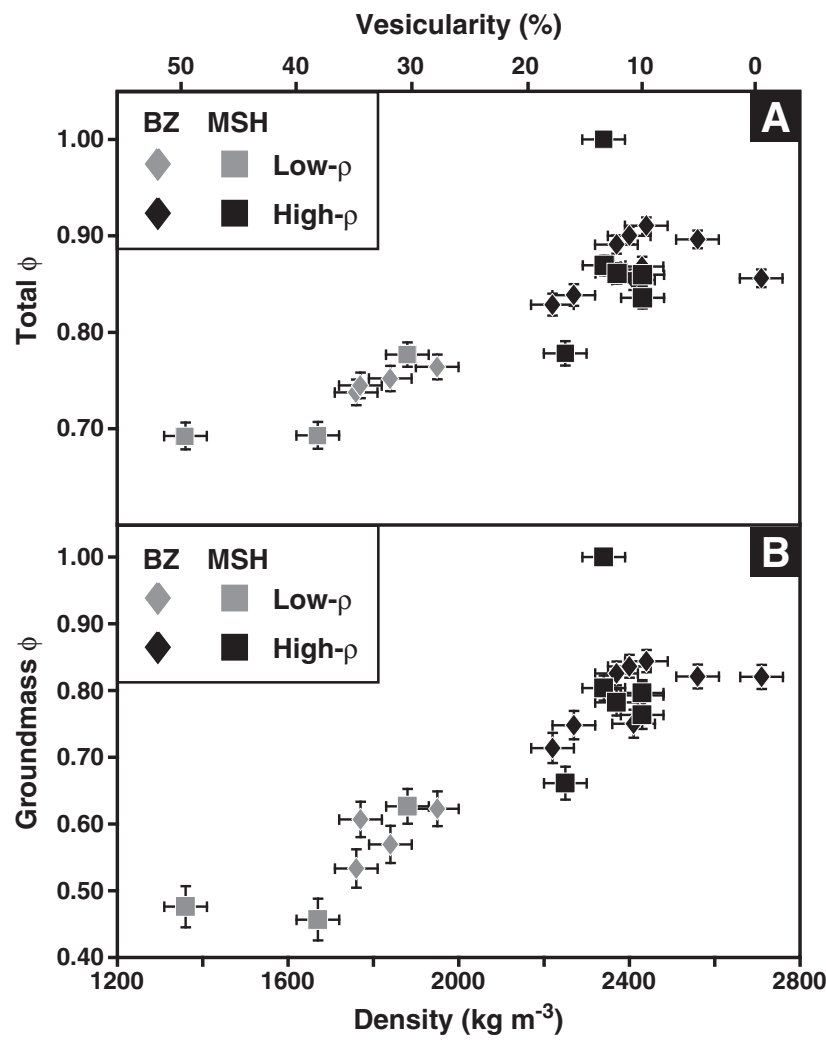

Fig. 3. Total (A) and groundmass (B) crystallinity of BZ and MSH blast clasts analyzed by point counting, expressed in volume fraction $(\phi)$ and calculated on a vesicle-free basis. Error bars indicate 2- $\sigma$ uncertainty. 


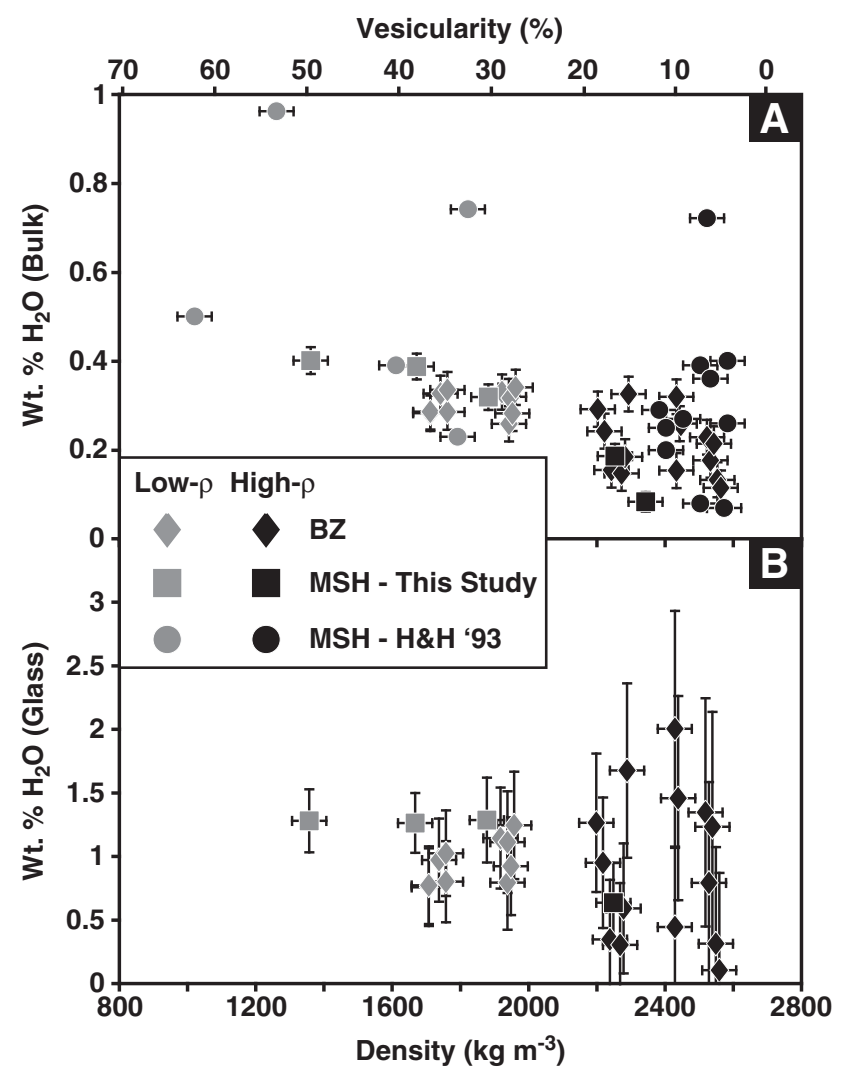

Fig. 4. (A) Bulk $\mathrm{H}_{2} \mathrm{O}$ contents, in weight percent, of BZ and MSH material measured by Karl Fischer Titration, supplemented with MSH data from by Hoblitt and Harmon (1993), referred to as $\mathrm{H} \& \mathrm{H}^{\prime} 93$ in the legend. Error bars indicate 2- $\sigma$ uncertainty. (B) Glass $\mathrm{H}_{2} \mathrm{O}$ concentrations of $\mathrm{BZ}$ and $\mathrm{MSH}$ blast material calculated by mass balance (see text for details). Error bars indicate 2- $\sigma$ uncertainty.

$\mathrm{H}_{2} \mathrm{O}$ in the designated hydrous phase or bulk rock. Solving for the $\mathrm{H}_{2} \mathrm{O}$ concentration in glass by algebraic manipulation:

$X_{\text {Glass }}^{\mathrm{H}_{2} \mathrm{O}}=\frac{X_{W R}^{\mathrm{H}_{2} \mathrm{O}}-\left(X_{\mathrm{Hbl}}^{\mathrm{H}_{2} \mathrm{O}}{ }^{\mathrm{H}} X_{W R}^{\mathrm{Hbl}}\right)}{X_{W R}^{G l a s s}}$.

Post-blast glass $\mathrm{H}_{2} \mathrm{O}$ contents are derived for all $\mathrm{BZ}$ and MSH clasts analyzed by KFT (Fig. 4).

The numerous uncertainties associated with each parameter on the right side of Eq. (2) lead to fairly large uncertainties in calculated glass $\mathrm{H}_{2} \mathrm{O}$ contents. The uncertainties associated with the calculation, $\pm 0.3-$ $0.9 \mathrm{wt} . \%$, generally compare favorably to the uncertainties associated with estimating glass $\mathrm{H}_{2} \mathrm{O}$ contents by electron microprobe as the difference between analytical totals and 100\% ( \pm 0.7 wt.\%, Devine et al., 1995; \pm 1 wt.\%, King et al., 2002). However, they are still large relative to calculated concentration values. Nevertheless, the average calculated glass $\mathrm{H}_{2} \mathrm{O}$ content at BZ ( 1-1.5 wt.\%) and the value calculated by Alidibirov et al. (1997) for MSH glass ( $1 \mathrm{wt} . \%)$ are (as expected) well below the initial melt $\mathrm{H}_{2} \mathrm{O}$ contents of 5-6 and 4.6 wt.\% for $\mathrm{BZ}$ and MSH, respectively (Kadik et al., 1986; Rutherford et al., 1985). Blast products at both sites are significantly outgassed with respect to initial magmastorage values.

Glass $\mathrm{H}_{2} \mathrm{O}$ contents can be used to estimate minimum pressures within the volcanic edifices prior to eruption. The average calculated glass $\mathrm{H}_{2} \mathrm{O}$ concentrations correspond to melt $\mathrm{H}_{2} \mathrm{O}$ solubility pressures of 10-20 MPa (Moore et al., 1998). Of course, the measurements cannot include volatiles lost during the blast by diffusion into new or preexisting vapor bubbles. However, Navon et al. (1998) suggest that nucleation could be severely restricted in relatively degassed, viscous silicic magmas such as those in the BZ and MSH domes, while Alidibirov
(1995) and Alidibirov et al. (1997) suggest that syn-eruptive mass transfer to pre-existing bubbles could be negligible, especially in smaller clasts. However, the 10-20 MPa range is consistent with the pre-blast conditions assumed for MSH by the models of Kieffer (1981a) and Alidibirov (1995), and with estimates of pre-blast lithostatic pressure at MSH (Eichelberger and Hayes, 1982). Notably, the release of 10-20 MPa of confining pressure is sufficient to fragment all but the densest pyroclastic material ejected by the blast stages of both volcanoes (Spieler et al., 2004).

\subsection{Phase compositions}

BZ clasts exhibit subtle evolution in plagioclase compositions between the low- and high-density materials (Fig. 5, Table A4-2). While microlites in low- and high-density clasts span approximately the same range of An contents (roughly $A_{30}-A n_{50}$ ), high-density clasts have microlites with 2-3 mol\% higher Or contents at a given An content. At MSH, the distinction between microlites in low- and highdensity materials is less clear (Fig. 5, Table A4-2); microlite compositions are similar between across all densities, although the most albitic grains all occur in the densest, holocrystalline clast.

$\mathrm{BZ}$ glasses (Table A4-3) progress from more primitive to more evolved compositions with increasing clast density and crystal content along the $0.1 \mathrm{MPa}$ cotectic (Fig. 6), indicating melt evolution driven by low-pressure crystallization (Blundy and Cashman, 2001).
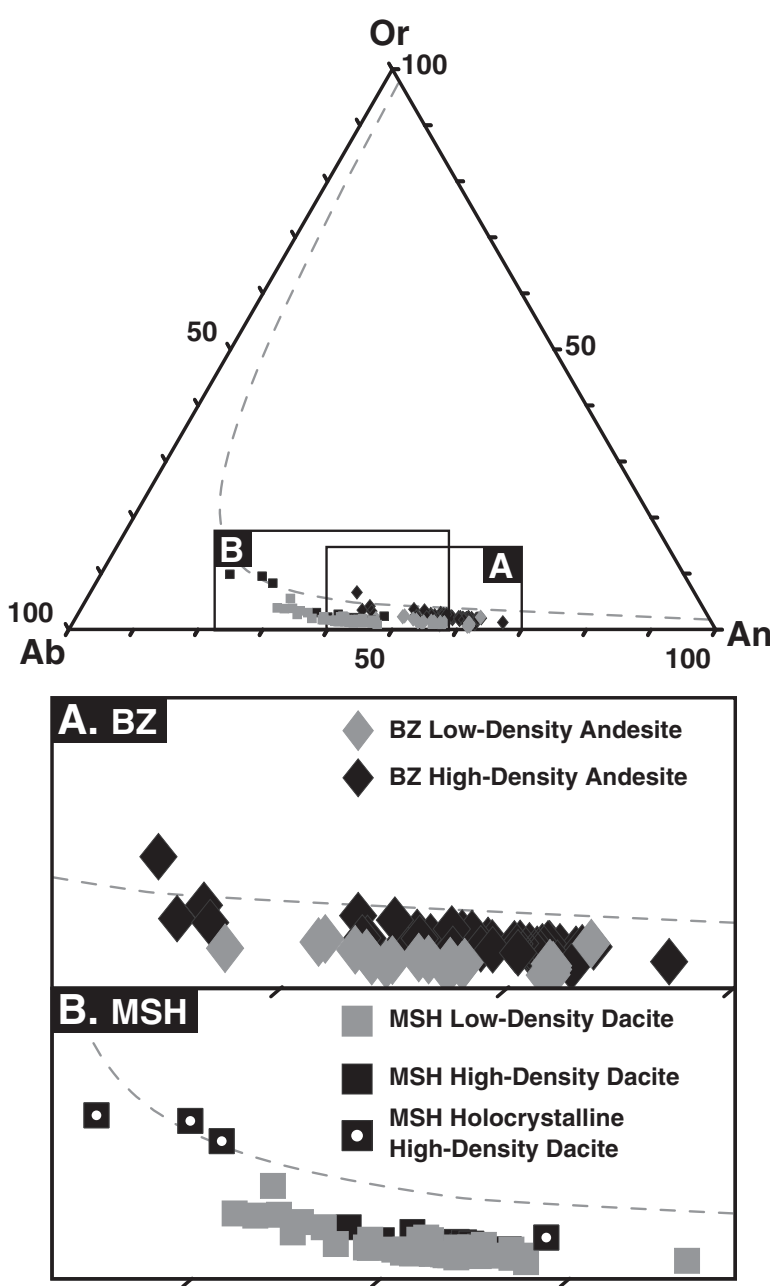

Fig. 5. Comparison of plagioclase microlite compositions from low- and high-density materials from BZ (A) and MSH (B), projected in An-Ab-Or space, with relevant portions of the diagram expanded for clarity. Feldspar solvus (dashed grey line) calculated using SOLVCALC (Wen and Nekvasil, 1994) and the thermodynamic model of Elkins and Grove (1990). See Appendix Table A4-2 for a full list of compositions. 


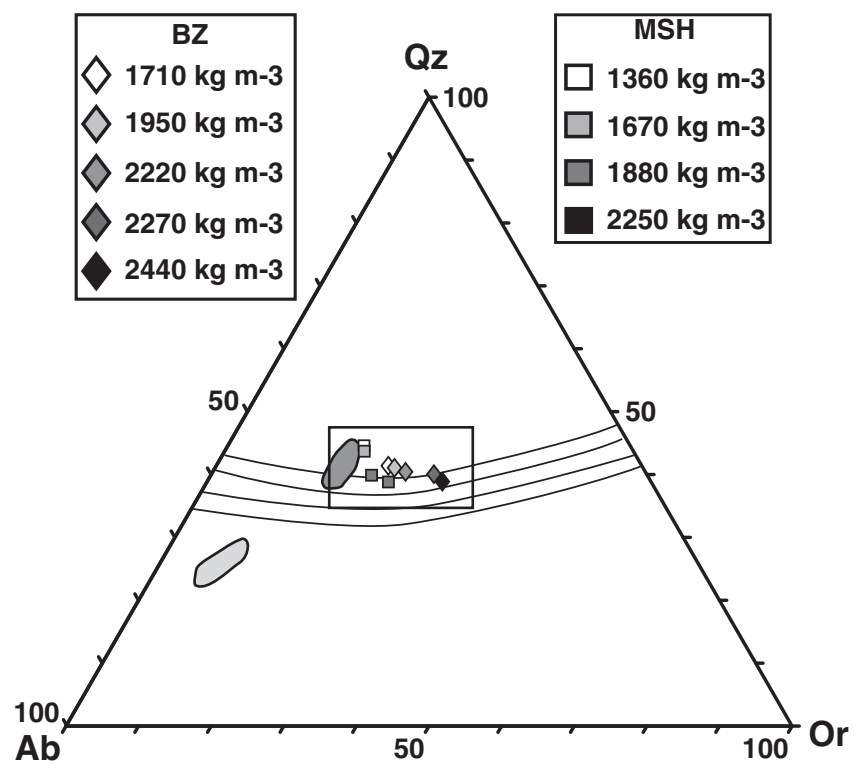

\section{A. BZ}

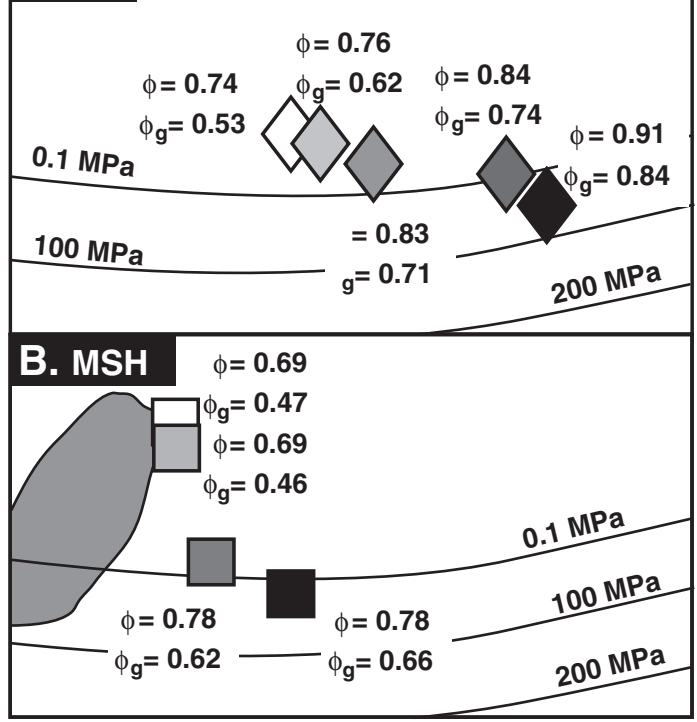

Fig. 6. Average glass compositions of $\mathrm{BZ}$ and MSH samples, projected into the $\mathrm{Q}-\mathrm{Ab}-\mathrm{Or}$ system (Tuttle and Bowen, 1958) using the projection scheme of Blundy and Cashman (2001), and refinements of cotectics by Brugger et al. (2003). Grey and white fields indicate groundmass glass compositions of post-blast 18 May 1980 grey and white pumice, respectively, erupted from MSH reported in Blundy and Cashman (2001). Inset box on ternary diagram is expanded, with BZ and MSH separated into panels A and B for clarity. The total $(\phi)$ and groundmass $\left(\phi_{\mathrm{g}}\right)$ crystal fraction of each clast are also noted. See Appendix Table A4-3 for a full list of compositions.

MSH glasses (Table A4-3) also progressively evolve with increasing crystallinity (Fig. 6). However, unlike BZ, compositions "overshoot" the $0.1 \mathrm{MPa}$ cotectic, and are supersaturated with silica.

\subsection{Hydrogen isotopes}

Hydrogen isotopic compositions of eruptive products are modified from magma reservoir values by open- and closed-system fractionations due to degassing prior to the blast (Taylor et al., 1983; Taylor, 1986; Newman et al., 1988; Dobson et al., 1989; Hoblitt and Harmon, 1993; Harford et al., 2003). Fractionation paths are modeled for BZ (see Appendix C for model details), assuming an initial $\partial \mathrm{D}$ value for $\mathrm{BZ}$ melt of $-45 \%$ ( (Pineau et al., 1999), and an initial melt $\mathrm{H}_{2} \mathrm{O}$ content of $5.5 \mathrm{wt} . \%$ (Kadik et al., 1986), and compared to the fractionation curves of Hoblitt and Harmon (1993). Although the sample set for BZ is limited, $\partial \mathrm{D}$ data for both blast and post-blast material is best explained by shallow opensystem fractionation (Fig. 7), related to the outgassing of the cryptodome material during ascent, emplacement and storage within the edifice. This is also the case for MSH (Hoblitt and Harmon, 1993).

\section{Discussion}

\subsection{Origin of holocrystalline MSH material}

Holocrystalline non-juvenile material is present in the MSH blast deposits; thus, the juvenile nature of the clast analyzed here must be verified. The holocrystalline high-density MSH clast (Fig. 3) shows no signs of alteration, and is indistinguishable in hand specimen from other high-density dacite. This clast contains the same phase assemblage of plagioclase, orthopyroxene, quartz, amphibole with well-developed reaction rims, Fe-Ti oxides, trace apatite and $\mathrm{K}$ feldspar, as found in other 1980 MSH eruption products (Rutherford et al., 1985; Rutherford and Hill, 1993). The compositions of plagioclase crystals span the same range (though also extending it) as in glass-bearing MSH blast clasts (Fig. 5). This clast was analyzed for major element chemistry by XRF, and has almost the exact same major element composition as the low-density and glass-bearing high-density MSH material reported both herein (Table 2) and in Hoblitt and Harmon (1993). Therefore, this holocrystalline clast is interpreted as juvenile MSH material that attained $100 \%$ crystallinity. At $880^{\circ} \mathrm{C}$ (the inferred magmatic temperature for MSH, Rutherford et al., 1985), and under very low-pressure (10-20 MPa) conditions, MSH magma is at near-solidus, or possibly sub-solidus conditions (see

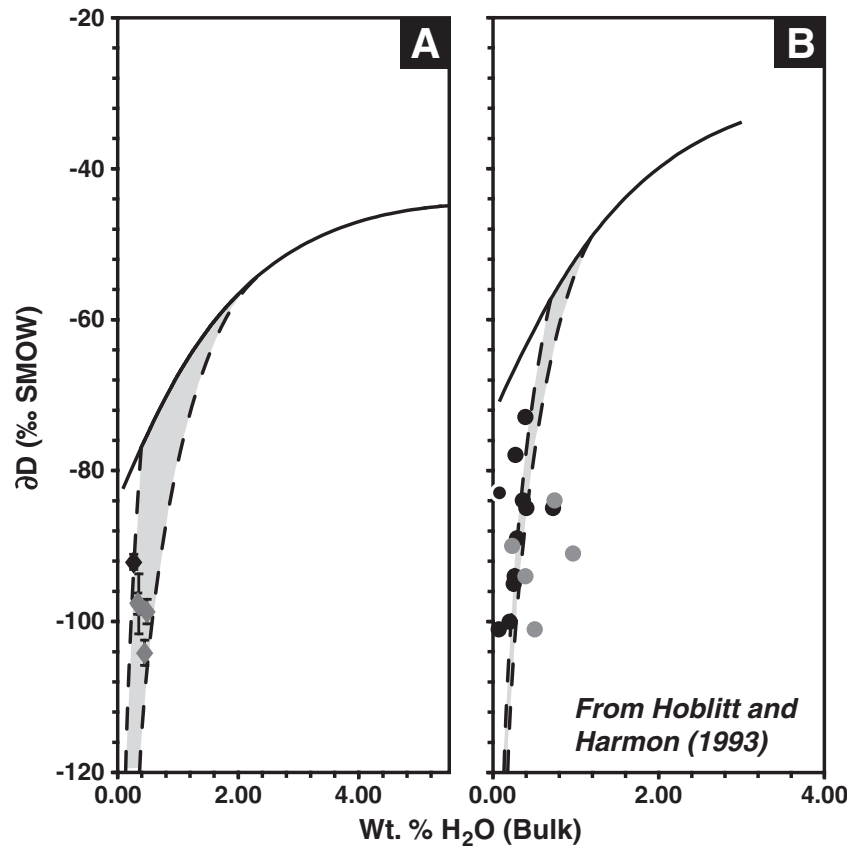

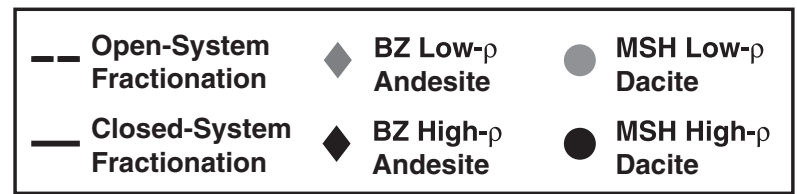

Fig. 7. (A) $\partial D$ values of BZ bulk-rock material shown in relation to modeled ideal openand closed-system $\partial \mathrm{D}$ fraction paths (see text for details). Values plotted are the averages of four repeat analyses, with error bars representing the reproducibility of the isotopic value obtained. Shaded areas represent the envelope enclosed by perfect closed-system fractionation paths beginning at minimum and maximum $\mathrm{H}_{2} \mathrm{O}$ contents (see text for details). Isotopic data and fractionation paths for MSH material, determined by Hoblitt and Harmon (1993), are shown in (B) for comparison. 
Table 2

Comparative XRF analyses of holocrystalline and glass-bearing MSH blast dacite. Oxides are in wt.\% with all $\mathrm{Fe}$ as $\mathrm{Fe}_{2} \mathrm{O}_{3}$.

\begin{tabular}{lccccc}
\hline Vol.\% crystals & 69 & 69 & 69 & 78 & 100 \\
\hline $\mathrm{SiO}_{2}$ & 64.7 & 65.0 & 64.9 & 64.7 & 64.4 \\
$\mathrm{TiO}_{2}$ & 0.64 & 0.62 & 0.63 & 0.59 & 0.64 \\
$\mathrm{Al}_{2} \mathrm{O}_{3}$ & 17.3 & 17.6 & 17.4 & 17.6 & 17.2 \\
$\mathrm{Fe}_{2} \mathrm{O}_{3}^{*}$ & 4.49 & 4.52 & 4.52 & 4.56 & 4.52 \\
$\mathrm{MnO}$ & 0.07 & 0.08 & 0.08 & 0.08 & 0.07 \\
$\mathrm{MgO}$ & 1.78 & 1.79 & 1.87 & 1.86 & 1.86 \\
$\mathrm{CaO}$ & 4.87 & 4.89 & 4.80 & 4.92 & 4.89 \\
$\mathrm{Na}_{2} \mathrm{O}$ & 4.60 & 4.49 & 4.59 & 4.41 & 4.59 \\
$\mathrm{~K}_{2} \mathrm{O}$ & 1.36 & 1.35 & 1.36 & 1.33 & 1.33 \\
$\mathrm{P}_{2} \mathrm{O}_{5}$ & 0.09 & 0.09 & 0.10 & 0.10 & 0.08 \\
$\mathrm{Total}_{\text {LOI }}$ & 99.9 & 100.4 & 100.2 & 100.1 & 99.6 \\
& 1.09 & 0.80 & 0.67 & 0.14 & -0.01 \\
\hline
\end{tabular}

Fig. 3 of Rutherford and Hill, 1993). The holocrystalline clast probably represents a portion of the MSH blast material that approached equilibrium at sub-solidus conditions, and may represent some of the first-intruded magma, which had the longest time to crystallize within the cryptodome.

\subsection{Evolution of crystallinity and phase compositions}

The progression of groundmass glass compositions towards more evolved compositions with increasing density and groundmass crystallinity (Fig. 6) probably results from progressive crystallization, which leads to the disparity in overall crystal content between lowand high-density materials. Primitive MSH matrix melt compositions from the most vesicular, least crystalline low-density material studied here are similar to the most evolved grey Plinian clasts analyzed by Blundy and Cashman (2001) and are more silica-rich than would be expected even at $0.1 \mathrm{MPa}$ (Fig. 6). Crystallization of quartz in the groundmass then returns the MSH samples to cotectic proportions in more microlite-rich material, with the initial silica excess a result of the kinetically-induced "lag" in quartz nucleation and crystallization observed by Brugger et al. (2003). At BZ, no such overshoot is observed; quartz is nearly ubiquitous in the post-blast Plinian-phase samples (Gorshkov and Bogoyavlenskaya, 1965; Plechov et al., 2008), indicating that the onset of quartz crystallization probably occurred earlier (with respect to melt differentiation) than at MSH. Instead, BZ matrix melt evolves essentially along the $0.1 \mathrm{MPa}$ cotectic with increasing crystallinity.

While cooling-induced crystallization has been observed in other shallow magma bodies such as dikes (e.g. Cashman, 1993) and lava lakes (e.g. Wright and Okamura, 1977), it seems unlikely to be the cause of the compositional evolution of BZ and MSH glasses. Direct and remote measurements of temperatures within post-1980 MSH extrusive domes were consistent with measurements of magmatic temperatures by mineral geothermometers (Rutherford et al., 1985), indicating that the temperature in the interior of such domes does not deviate much from crustal magmatic storage conditions over time scales comparable to the periods leading up to the BZ and MSH blasts (Dzurisin et al., 1990; Schneider et al., 2008). Furthermore, the latent heat released due to crystallization is likely to be significant in these domes, and could also serve to counteract any effects of cooling (Blundy et al., 2006), either by adiabatic gas expansion (e.g. Sparks and Pinkerton, 1978) or heat loss to the ambient country rock. Based on both conductive cooling models and cooling rates determined by studies of progressive magnetization (Dzurisin et al., 1990), Hoblitt and Harmon (1993) estimate that the chilled margins of the BZ and MSH cryptodomes would be no wider than a few meters, probably accounting for $<5 \%$ of the total volume of each cryptodomes. The same geometry is assumed here for the BZ cryptodome. Because the highdensity material accounts for $\sim 65 \%$ of the total volume of juvenile products at BZ (Belousov et al., 2007) and 28\% of the deposits at MSH
(Hoblitt and Harmon, 1993), it is unlikely that cooling-driven crystallization could generate the crystallinity disparity between low- and high-density materials (Figs. 3, 8). Hoblitt and Harmon (1993) assumed that the MSH cryptodome was a near-spherical body cooling from the outside, a reasonable approximation given the geometry, endogenous growth and cooling behavior observed in nonfragmented silicic cryptodomes (e.g. Goto and McPhie, 1998; Stewart and McPhie, 2003). Furthermore, magma emplacement flux was highest in the earliest stages of cryptodome emplacement (Voight et al., 1981), implying that the rudimentary geometry of the cryptodome was likely established early in the cryptodome-building stage.

Cashman $(1988,1992)$ inferred magmatic degassing as the likely driving force for groundmass crystallization within the MSH dome. The same process is probably operative at BZ, and therefore the difference in groundmass crystallinity between low- and high-density materials likely reflects the differential degassing of BZ and MSH cryptodome melts (Fig. 8). The degassing of cryptodome magma at both MSH and BZ led to an increase in liquidus temperatures, resulting in an effective undercooling that drove microlite growth (e.g. Geschwind and Rutherford, 1995). At both BZ and MSH, degassing of the decompressed magma body appears sufficient to drive groundmass crystallization within the entire cryptodome (Cashman, 1992). Furthermore, assuming the magma intruding into the cryptodomes was fairly homogeneous (Gorshkov and Bogoyavlenskaya, 1965; Plechov et al., 2008), more time would be required to achieve the highly evolved melt compositions and crystallinities (Fig. 3) observed in high-density material. Thus, the portions of the cryptodome magma that became high-density pyroclastic material likely experienced longer residence time in the cryptodome.

\subsection{Models for the formation of bimodal density distributions}

The origin of bimodal density distributions associated with directed blasts has been addressed previously in varying degrees of detail

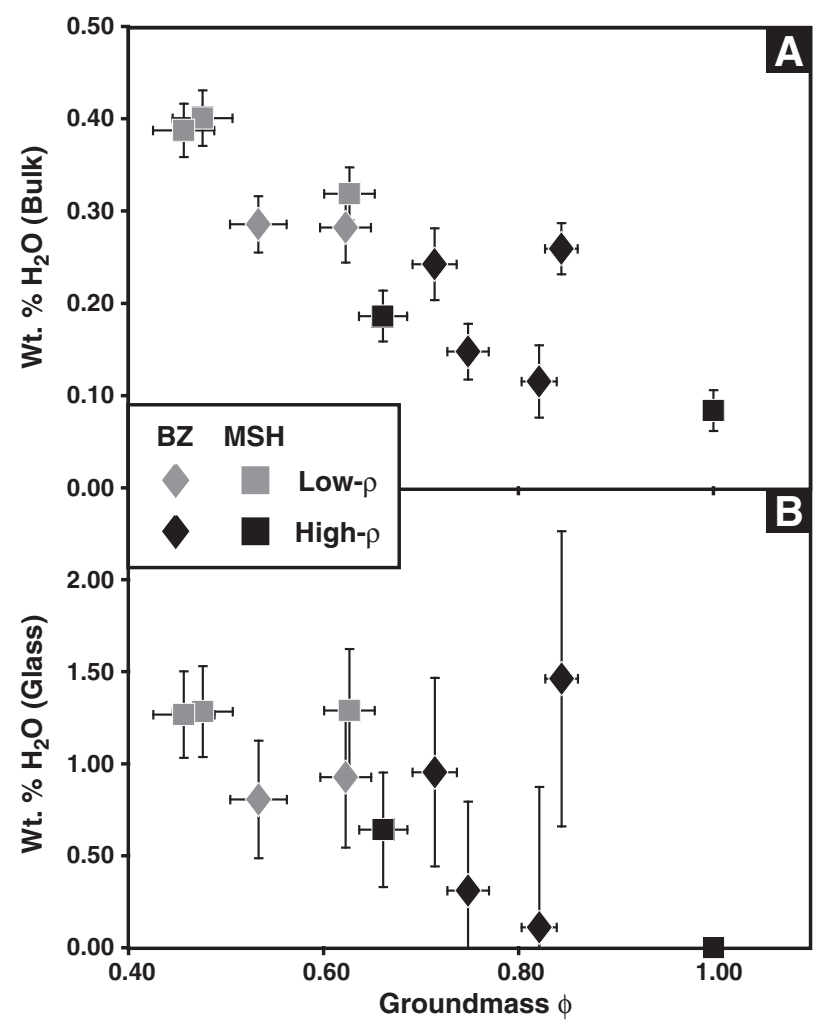

Fig. 8. Groundmass crystal fraction ( $\phi$ ) of $\mathrm{BZ}$ and MSH blast material related to bulk (A) and glass (B) $\mathrm{H}_{2} \mathrm{O}$ content. More degassed material generally shows higher crystal contents than more volatile-rich clasts, though this is not uniformly the case. 
(Hoblitt and Harmon, 1993; Alidibirov et al., 1997; Cashman and Hoblitt, 2004; Belousov et al., 2007). The dominant mechanism is inferred to be a heterogeneous distribution of volatiles within cryptodome magma prior to fragmentation. This interpretation is partly supported by the data presented herein (Fig. 4). If portions of the magma that remained dense lacked both volatiles and vesicles prior to the blast (Hoblitt and Harmon, 1993; Alidibirov et al., 1997), it would be impossible for these portions to experience bubble growth during fragmentation. However, the new measurements of crystallinity (Fig. 3) and bulk $\mathrm{H}_{2} \mathrm{O}$ (Fig. 4) suggest that another process is also important.

The amount of volatile energy stored in cryptodome bubbles cannot be quantified accurately from analysis of blast deposit material. However, the variety of post-blast volatile contents of $\mathrm{BZ}$ and MSH material does indicate that portions of the cryptodome magma retained significant volatiles, while other portions were completely outgassed and consequently lost the potential for bubble expansion and fragmentation synblast. Admittedly, some of the high-density material is volatile-poor (i.e., $<0.2$ wt.\%) compared to low-density clasts ( $\geq 0.2$ wt.\%; Fig. 4). However, a majority of high-density clasts analyzed contains bulk $\mathrm{H}_{2} \mathrm{O}$ comparable in concentration to that of low-density clasts (0.3-0.4 wt.\%). In fact, the bulk $\mathrm{H}_{2} \mathrm{O}$ contents of low- and high-density BZ and MSH materials analyzed in this study and by Hoblitt and Harmon (1993) range from $\sim 0.2-1$ and $\sim 0.05-0.75$ wt.\%, respectively (Fig. 4A). The glass $\mathrm{H}_{2} \mathrm{O}$ contents of the lowand high-density materials may range from $\sim 0.5$ to 1.5 and $\sim 0$ to $3 \mathrm{wt} . \%$, respectively (Fig. 4B), allowing for the high degrees of uncertainty and assuming syn-eruptive mass transfer is minimal (Alidibirov et al., 1997). In other words, there is no sharp contrast in bulk or glass $\mathrm{H}_{2} \mathrm{O}$ between low- and high-density materials at $\mathrm{BZ}$ and $\mathrm{MSH}$; instead, the significant overlap in both glass and bulk $\mathrm{H}_{2} \mathrm{O}$ indicates that a portion of the highdensity material at BZ and MSH had not outgassed, and like the lowdensity material, was volatile-charged prior to the fragmentation. If volatile content is the dominant controlling factor in determining whether or not a clast experiences bubble expansion during a volcanic blast, why then did some volatile-charged material not experience syn-blast bubble expansion?

Quenching due to cooling along the margins of the cryptodome potentially locks in elevated volatile contents. Of the BZ and MSH high-density material, $\sim 65$ and $70 \%$ respectively of clasts analyzed have bulk $\mathrm{H} 2 \mathrm{O}$ contents greater than $0.2 \mathrm{wt} . \% \mathrm{H}_{2} \mathrm{O}$, the lower limit of the vesiculation threshold proposed by Hoblitt and Harmon (1993), and, $\sim 20$ and 30\%, respectively, of clasts analyzed have bulk $\mathrm{H}_{2} \mathrm{O}>0.3$ wt.\% (the median threshold value). As has been noted, high-density clasts are 65 and $28 \%$ of the total volume of juvenile blast material from the BZ and MSH eruptions (Hoblitt and Harmon, 1993; Belousov et al., 2007). Therefore if this sample set is assumed to be representative, 10-40 and 9-20 vol.\% of the BZ and MSH cryptodomes, respectively, would have consisted of magma that remained dense, despite having volatile contents potentially sufficient to vesiculate during decompression. The calculations of Hoblitt and Harmon (1993) showed that the quenched margins account for no more than $5 \%$ of the cryptodome (and possibly quite a bit less). Thus, while post-emplacement quenching along cryptodome margins could account for some of the volatile-rich high-density material, it cannot account for all of this material.

Many factors have been identified as important in controlling the rheology of magmas in volcanic environments. At high solid fractions $(\phi>0.5)$, magmas are non-Newtonian substances, with behavior dependent on strain rate (Stevenson et al., 1996; Vigneresse and Tikoff, 1999; Lavallée et al., 2007) and on the rate of applied stress (Dingwell, 1997). The viscosity of the interstitial melt is less influential at higher solid fractions (Lavallee et al., 2007), although it does play some role and can vary over several orders of magnitude depending on melt $\mathrm{H}_{2} \mathrm{O}$ content and temperature (Giordano et al., 2008). Crystal size and shape, and heterogeneities therein, control the effects of crystal-crystal interactions on rheology, such as the onset of non-Newtonian behavior and development of yield strength (Yu and
Standish, 1993; Hoover et al., 2001; Ishibashi and Sato, 2007). Although models for the rheological behavior and emplacement of highly crystalline magmas continue to improve (Costa et al., 2009; Massol and Jaupart, 2009), no widely-accepted standard model exists for how highly crystalline magmas respond to applied stress. Nevertheless, assuming all other parameters (applied stress, temperature, melt viscosity, etc.) are equal, a more crystalline magma is unquestionably more viscous than a less crystalline magma (Petford, 2003).

As the phenocryst proportions are approximately equal across the range of clast densities, variations in the bulk crystallinity of BZ and MSH blast material arise from variations in groundmass crystallinity and are correlative with clast density (Fig. 3). In fact, the bulk crystallinity shows a continuum very similar to the density trend seen in BZ and MSH blast material. If $2000 \mathrm{~kg} / \mathrm{m}^{3}$ is the threshold between low- and high-density materials (Hoblitt and Harmon, 1993), then all low-density material falls in the range $\phi=0.70-0.78$, while all highdensity material with a single exception gives $\phi \geq 0.80$ (Fig. 3). In absolute terms, this range of crystallinity is small. Yet at high crystal fractions, the difference in bulk viscosity between magma with $\phi=0.70$ and $\phi=0.80$ could be as much as a few orders of magnitude (Figs. 2 and 3 of Costa et al., 2009, and references therein). Increased magma viscosity inhibits bubble growth (Thomas et al., 1994; Toramaru, 1995; Barclay et al., 1995; Proussevitch and Sahagian, 1998), which suggests that rheological factors might have retarded vesiculation of highly crystalline magma during cryptodome fragmentation (Fig. 9). The crystallinity threshold between low- and highdensity materials is similar to the Particle Locking Threshold (PLT) of Vigneresse et al. (1996). The PLT occurs at $\phi>0.70-0.75$ (or possibly higher, depending on the sizes and shapes of the crystals), above which the melt phase loses connectivity, and the rheology of the magma passes from Bingham fluid behavior to plastic, high yieldstrength solid behavior (Vigneresse et al., 1996; Hrouda et al., 1999). The PLT is formulated for magmas crystallizing and deforming in a plutonic setting, and may not be strictly relevant to volcanic blasts, in which the applied rates of strain are exceedingly high. However, the loss of melt connectivity at $\phi \sim 0.75$ could represent a point where crystal-crystal interactions prevent vesicles from expanding during a volcanic blast, thus giving rise to high-density clasts.

\subsection{Implications for clast density distributions}

Thresholds in crystallinity and volatile content may explain why the relative abundances of the low- and high-density materials at BZ contrast with those at MSH. At BZ, the high-density mode is dominant ( 65 vol.\% Belousov et al., 2007), while at MSH the low-density mode is dominant ( 72 vol.\%, Hoblitt and Harmon, 1993) and is slightly less dense than the BZ low-density material (Fig. 1). Magma flux probably

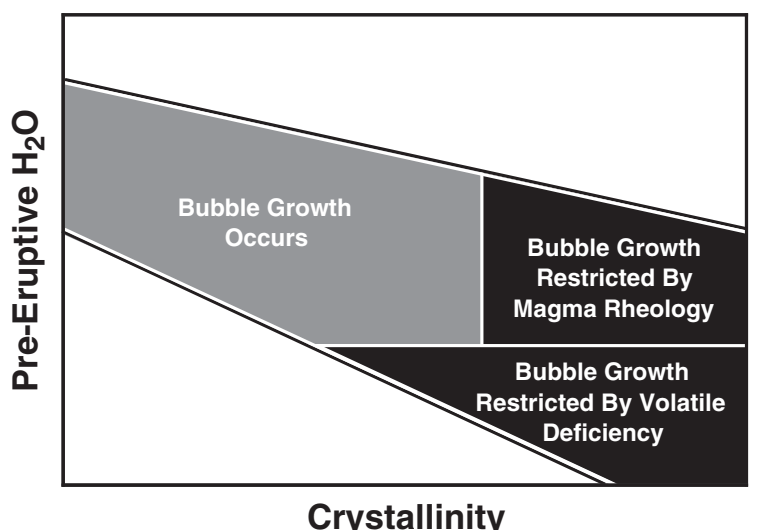

Fig. 9. Schematic representation of the crystallinity and volatile content thresholds that could inhibit syn-blast bubble expansion of cryptodome magma during a directed blast. 
peaked in the early stages of cryptodome formation (Voight et al., 1981; Belousov et al., 2007). At BZ, this magma would have had more than four months to outgas and crystallize - a process made easier by the exposure of a small portion of the dome at the summit (Belousov, 1996) - while MSH magma would have had only two months. If the BZ magma was in the cryptodome longer and could outgas more easily, it would have had more time to outgas and crystallize beyond the volatile and crystallinity thresholds for bubble expansion. Thus, the dominance of the high-density mode and the slightly higher density of the low-density ejecta at BZ compared with MSH are plausibly attributed to differences in residence time. Furthermore, if cryptodome growth was pseudo-endogenous (filled from within, e.g. Goto and McPhie, 1998)-as opposed to pseudo-exogeneous, or lobedmagma in contact with wall rock would have been both oldest with respect to injection age and more susceptible to gas loss (cf. Hoblitt and Harmon, 1993).

\subsection{Implications for eruptive style}

The $\mathrm{H}_{2} \mathrm{O}$ preserved in the glasses of blast materials (0.05-2.0 wt.\%) is dwarfed by $\mathrm{H}_{2} \mathrm{O}$ dissolved in melt at reservoir conditions ( $\geq 5$ wt.\%). However, while this difference represents the $\mathrm{H}_{2} \mathrm{O}$ lost during ascent and emplacement, analytical methods do not permit evaluation of the amount of $\mathrm{H}_{2} \mathrm{O}$ present in crypodome magma bubbles, which would be necessary for full accounting of the $\mathrm{H}_{2} \mathrm{O}$ budget for these eruptions. Rather, this analysis of blast materials concerns the processes giving rise to bimodal distribution of pyroclast densities and the conundrum of excess dissolved volatiles that remain in the clasts despite having been available to drive vesiculation.

The negative correlation between crystal content and syn-blast vesiculation could have significant effects on eruptive style in a variety of volcanic settings. Spieler et al. (2004) showed that the amount of energy necessary to fragment a melt increases with decreasing melt porosity. If high crystal contents exert some control over bubble expansion, then the efficiency of magma fragmentation will be in part controlled by the crystallinity of that magma. Belousov et al. (2002) report the occurrence of similar control during the 1997 eruption of BZ, where the high crystallinity and limited vesiculation of juvenile material ejected in the opening phases of the eruption favored the production of block-and-ash flows, while the introduction of less crystalline, more volatile-charged magma rapidly ascended from depth enabled reduced clast porosities, less dense eruption mixtures, and the development of a partially stable eruption column. The differences in textures reflect mainly the microlite content of the groundmass. Similarly, Gardner et al. (1998) proposed that crystallization, driven by degassing, increased the energies required for fragmentation during the 1992 eruption of Crater Peak, Alaska; eruption termination was attributed to the magma becoming too crystalline, and by extension, too viscous, to fragment (Gardner et al., 1998).

These observations could be relevant to the BZ and MSH blasts. To what degree does magma outgassing and crystallization, prior to the fragmentation of a silicic cryptodome, influence the forces that propel a directed blast? Although the BZ blast deposit is volumetrically larger than MSH, and was produced by a larger cryptodome mass, it covered an area $\sim 100 \mathrm{~km}^{2}$ smaller (Hoblitt et al., 1981; Belousov, 1996; Belousov et al., 2007), and was less widely dispersed in lateral directions (Fig. 2). Furthermore, the MSH blast encountered topographic features that impeded transport, though they may also have promoted lateral expansion (Hoblitt et al., 1981; Voight et al., 2009), whereas the BZ blast traveled across less irregular, more steeply dipping terrain (Belousov et al., 2007). Was the BZ blast less powerful? BZ contained a much higher proportion of dense clasts (Belousov et al., 2007), with corresponding high bulk crystallinity and lower bulk volatile content in cryptodome magma. This could suggest that the blast would have been less energetic per unit mass at BZ, compared to MSH, because the cryptodome magma possessed less potential volatile energy for expansion, and was less efficient in expelling the stored energy it did possess. Conversely, the grain size distributions of the BZ and MSH blast deposits are very similar, with the BZ blast deposits being very slightly finer overall (Belousov et al., 2007); this could indicate that the BZ blast was actually more powerful, causing more efficient fragmentation of the cryptodome magma, and resulting in finer-grained deposits. Further advanced models of blast dynamics at MSH and BZ will be useful in addressing these questions (cf. Kieffer, 1981b; Esposti Ongaro et al., 2008; Voight et al., 2009).

\section{Conclusions}

Heterogeneity in the open-system outgassing of the cryptodome at BZ qualitatively mirrors that observed at MSH (Hoblitt and Harmon, 1993). At both BZ and MSH, interstitial melt in blast material is significantly degassed relative to initial magma-storage conditions at depth. While a portion of the high-density clasts are more outgassed than low-density material at both MSH and BZ, a significant portion of high-density clasts appears to contain bulk volatile $\left(\mathrm{H}_{2} \mathrm{O}\right)$ contents comparable to low-density clasts. Glass $\mathrm{H}_{2} \mathrm{O}$ contents are also similar, though they must be considered within the bounds of measurement precision and error. Therefore the high-density portion of these blast deposits can only be partially ascribed to inhomogeneous outgassing. Melt degassing in the volcanic edifices of both BZ and MSH probably drove significant crystallization after the formation of the cryptodome. This crystallization is reflected in the heightened groundmass crystallinity (and, consequently, bulk crystallinity) of high-density relative to the low-density material, and in glass compositions, which become progressively more evolved with increasing clast density.

The difference in crystal content between low- and high-density materials suggests a link between heightened crystallinity and synblast vesiculation process, such that some of the high-density material derived from a portion of the cryptodome magma that was unable to experience bubble growth during the blast due to rheological considerations (Fig. 9), despite being relatively rich in volatiles. The remaining high-density material derived from cryptodome magma that did not vesiculate during the blast due to extensive outgassing prior to fragmentation (e.g. Hoblitt and Harmon, 1993). The longer cryptodome-building period at BZ, and the more open nature of the BZ cryptodome, led to the attainment of critical values of volatile deficiency and crystal content in a larger proportion of the BZ cryptodome magma than in the MSH cryptodome. This probably led to the dominance of the high-density mode at BZ, contrasting with MSH where the cryptodome emplacement period was shorter and the low-density mode was dominant. Improved models of the fluid dynamics of the BZ blast will help answer whether a real difference in the power of the BZ and MSH blasts exists, and what roles pre-blast outgassing and crystallinity play in such a discrepancy.

Supplementary materials related to this article can be found online at doi:10.1016/j.jvolgeores.2010.09.011.

\section{Acknowledgments}

Constructive reviews by M.L. Coombs and an anonymous reviewer, and discussions with C.R. Brugger, R.P. Hoblitt, B.F. Houghton, T. Shea, J.M. Sinton and L.T. Petrochilos greatly improved this manuscript. E. Hellebrand is gratefully acknowledged for copious assistance with EPMA and XRF analyses. J.M. Becker, J.A. Bowles, C. Fraley, A. von der Handt, G.R. Huss, M.O. Garcia, G. Moore, K. Nagashima, K.H. Rubin and J.M. Sinton are thanked for analytical assistance. L.D. Almberg, M.J. Rutherford, J.S. Shipman, K. Genareau, and W.K. Stovall provided samples and images. Special thanks are due to the 2008 PIRE-Kamchatka team for invaluable assistance in fieldwork, to T.W. Vennemann for performing the manometry analyses and to J.F. Larsen, R.J. Newberry, K.P. Severin and 
the U. Alaska Fairbanks Experimental Petrology group for the use of KFT and lab spaces. Financial support for this work was provided by the Amherst College John Mason Clarke 1877 Fellowship to OKN, by the NSF PIRE-Kamchatka Award OISE 0530278 to J.E. Eichelberger, and by NSF CAREER Award EAR04-49888 to JEH. This is SOEST contribution \#7997.

\section{References}

Adams, N.K., Houghton, B.F., Hildreth, W., 2006. Abrupt transitions during sustained explosive eruptions: examples from the 1912 eruption of Novarupta, Alaska. Bull. Volcanol. 69, 189-206.

Alidibirov, M.A., 1995. A model for the mechanism of the May 18, 1980 Mount St. Helens blast. Bull. Volcanol. 66, 217-225.

Alidibirov, M.A., Dingwell, D.B., 1996. Magma fragmentation by rapid decompression. Nature 380, 146-149.

Alidibirov, M.A., Bogoyavlenskaya, G.E., Kirsanov, I.T., Firstov, P.P., Girina, O.A., Belousov, A.B., Zhdanova, E.Yu., Malyshev, A.I., 1990. The 1985 eruption of Bezymiannyi [sic]. Volcanol. Seismol. 10, 839-863.

Alidibirov, M.A., Dingwell, D.B., Stevenson, R., Hess, K.-U., Webb, S.L., Zinke, J., 1997. Physical properties of the Mt. St. Helen's cryptodome magma. Bull. Volcanol. 59, 103-111.

Anderson, S.W., Fink, J.H., 1989. Hydrogen-isotope evidence for extrusion mechanisms of the Mount St Helens lava dome. Nature 341, 521-523.

Barclay, J., Riley, R.S., Sparks, R.S.J., 1995. Analytical models for bubble growth during decompression of high viscosity magmas. Bull. Volcanol. 57, 422-431.

Behrens, H., 1995. Determination of water solubilities in high-viscosity melts: an experimental study on $\mathrm{NaAlSi}_{3} \mathrm{O}_{8}$ and $\mathrm{KAlSi}_{3} \mathrm{O}_{8}$ melts. Eur. J. Mineral. 7, 905-920.

Behrens, H., Stuke, A., 2003. Quantification of $\mathrm{H}_{2} \mathrm{O}$ contents in silicate glasses using IR spectroscopy - a calibration based on hydrous glasses analysed by Karl Fischer Titration. Glass Sci. Technol. 76, 176-289.

Belousov, A.B., 1996. Deposits of the 30 March 1956 directed blast at Bezymianny Volcano, Kamchatka, Russia. Bull. Volcanol. 57, 649-662.

Belousov, A.B., Bogoyavlenskaya, G.E., 1988. Debris avalanche of the 1956 Bezymianny eruption. Proc. Kagoshima Int. Conf. Volc., pp. 460-462.

Belousov, A.B., Voight, B., Belousova, M.G., Petukhin, A., 2002. Pyroclastic surges and flows from the 8-10 May 1997 explosive eruption of Bezymianny Volcano, Kamchatka, Russia. Bull. Volcanol. 64, 455-471.

Belousov, A.B., Voight, B., Belousova, M.G., 2007. Directed blasts and blast-currents: a comparison of the Bezymianny 1956, Mount St Helens 1980, and Soufriere Hills, Montserrat 1997 eruptions and deposits. Bull. Volcanol. 69, 701-740.

Blundy, J., Cashman, K.V., 2001. Ascent-driven crystallization of dacite magmas at Mount St Helens, 1980-1986. Contrib. Mineral. Petrol. 140, 631-650.

Blundy, J., Cashman, K.V., Humphreys, M.C.S., 2006. Magma heating by decompressiondriven crystallization beneath andesite volcanoes. Nature 443, 76-80.

Bogoyavlenskaya, G.E., Braitseva, O.A., Melekestsev, I.V., Kirianov, V.Yu., Miller, C.D. 1985. Catastrophic eruptions of the directed blast type at Mount St. Helens, Bezymyanny [sic] and Shiveluch volcanoes. J. Geodyn. 3, 189-218.

Brugger, C.R., Johnston, A.D., Cashman, K.V., 2003. Phase relations in silicic systems at one-atmosphere pressure. Contrib. Mineral. Petrol. 146, 356-369.

Cashman, K.V., 1988. Crystallization of Mount St. Helens 1980-1986 dacite: a quantitative textural approach. Bull. Volcanol. 50, 194-209.

Cashman, K.V., 1992. Groundmass crystallization of Mount St. Helens dacite, 1980 1986: a tool for interpreting shallow magmatic processes. Contrib. Mineral. Petrol. 109, 431-449.

Cashman, K.V., 1993. Relationship between plagioclase crystallization and cooling rate in basaltic melts. Contrib. Mineral. Petrol. 113, 126-142.

Cashman, K.V., Hoblitt, R.P., 2004. Magmatic precursors to the 18 May 1980 eruption of Mount St Helens. Geology 32, 141-144.

Cashman, K.V., Taggart, J.E., 1983. Petrologic monitoring of 1981-1982 eruptive products from Mount St. Helens, Washington. Science 221, 1385-1387.

Christiansen, R.L., Peterson, D.W., 1981. Chronology of the 1980 eruptive activity. In: Lipman, P.W., Mullineaux, D.R. (Eds.), The 1980 Eruptions of Mount St. Helens, Washington: U.S. Geol. Surv. Prof. Pap., 1250, pp. 17-30.

Costa, A., Caricchi, L., Bagdassarov, N., 2009. A model for the rheology of particle-bearing suspensions and partially molten rocks. Geochem. Geophys. Geosyst. 10, Q03010.

Crandell, D.R., Hoblitt, R.P., 1986. Lateral blasts at Mount St. Helens and hazard zonation. Bull. Volcanol. 48 (1), 27-37.

Devine, J.D., Gardner, J.E., Brack, H.P., Layne, G.D., Rutherford, M.J., 1995. Comparison of microanalytical methods for estimating $\mathrm{H}_{2} \mathrm{O}$ contents of silicic volcanic glasses. Am. Mineral. 80 (3-4), 319-328.

Dingwell, D.B., 1997. The brittle-ductile transition in high-level granitic magmas: material constraints. J. Petrol. 38 (12), 1635-1644.

Dobson, P.F., Epstein, S., Stolper, E.M., 1989. Hydrogen isotope fractionation between coexisting vapo and silicate glasses and melts at low pressure. Geochim. Cosmochim. Acta 53, 554-572.

Donovan, J.J., Kremser, D., Fournelle, J.H., 2007. Probe for Windows User's Guide and Reference, Enterprise Edition. Probe Software, Inc., Eugene, OR. 355 pp.

Dzurisin, D., Denlinger, R.P., Rosenbaum, J.G., 1990. Cooling rate and thermal structure determined from progressive magnetization of the dacite dome at Mount St. Helens, Washington. J. Geophys. Res. 95, 2763-2780.

Eichelberger, J.C., Hayes, D.B., 1982. Magmatic model for the Mount St. Helens blast of May 18, 1980. J. Geophys. Res. 87, 7727-7738.

Elkins, L.T., Grove, T.L., 1990. Ternary feldspar experiments and thermodynamic models. Am. Mineral. 75, 544-559.
Esposti Ongaro, T., Clarke, A.B., Neri, A., Voight, B., Widiwidjayanti, C., 2008. Fluid dynamics of the 1997 Boxing Day volcanic blast on Montserrat, West Indies. J. Geophys. Res. 113, B03211.

Gardner, C.E., Cashman, K.V., Neal, C.A., 1998. Tephra-fall deposits from the 1992 eruption of Crater Peak, Alaska: implications of clast textures for eruptive processes. Bull. Volcanol. 59, 537-555.

Geschwind, C., Rutherford, M.J., 1995. Crystallization of microlites during magma ascent: the fluid mechanics of recent eruptions at Mount St. Helens. Bull. Volcanol. 57, 356-370.

Giordano, D., Russell, J.K., Dingwell, D.B., 2008. Viscosity of magmatic liquids: a model. Earth Planet. Sci. Lett. 271, 123-134.

Gorshkov, G.S., 1959. Gigantic eruption of the Bezymianny Volcano. Bull. Volcanol. 20, 77-109.

Gorshkov, G.S., 1963. Directed volcanic blasts. Bull. Volcanol. 26, 83-88.

Gorshkov, G.S., Bogoyavlenskaya, G.E., 1965. Bezymyannyi [sic] Volcano and Peculiarities of Its Last Eruption (1955-1963). Nauka, Moscow. (in Russian).

Goto, Y., McPhie, J., 1998. Endogenous growth of a Miocene submarine dacite cryptodome, Rebun Island, Hokkaido, Japan. J. Volcanol. Geotherm. Res. 84, 273-286.

Gurioli, L., Houghton, B.F., Cashman, K.V., Cioni, R., 2005. Complex changes in eruption dynamics and the transition between Plinian and phreatomagmatic activity during the 79 AD eruption of Vesuvius. Bull. Volcanol. 67, 144-159.

Hammer, J.E., Rutherford, M.J., 2002. An experimental study of the kinetics of decompression induced crystallization in silicic melt. J. Geophys. Res. 107 (B1), 2021.

Hammer, J.E., Cashman, K.V., Voight, B., 2000. Magmatic processes revealed by textural and compositional trends in Merapi dome lavas. J. Volcanol. Geotherm. Res. 100, 165-192.

Harford, C.L., Sparks, R.S.J., Fallick, A.E., 2003. Degassing at the Soufriere Hills Volcano, Montserrat, recorded in matrix glass compositions. J. Petrol. 44, 1503-1523.

Hoblitt, R.P., 2000. Was the 18 May 1980 lateral blast at Mt St Helens the product of two explosions? Philos. Trans. R. Soc. London 358, 1639-1661.

Hoblitt, R.P., Harmon, R.S., 1993. Bimodal density distribution of cryptodome dacite from the 1980 eruption of Mount St. Helens, Washington. Bull. Volcanol. 55, 421-437.

Hoblitt, R.P., Miller, C.D., Vallance, J.W., 1981. Origin and stratigraphy of the deposit produced by the May 18 directed blast. In: Lipman, P.W. Mullineaux, D.R. (Eds.), The 1980 Eruptions of Mount St. Helens, Washington: U.S. Geol. Surv. Prof. Pap., 1250 , pp. 401-419.

Hoover, S.R., Cashman, K.V., Manga, M., 2001. The yield strength of subliquidus basalts experimental results. J. Volcanol. Geotherm. Res. 107, 1-18.

Houghton, B.F., Wilson, C.J.N., 1989. A vesicularity index for pyroclastic deposits. Bull. Volcanol. 51, 451-462.

Hrouda, F., Taborska, S., Schulmann, K., Jezek, J., Dolejs, D., 1999. Magnetic fabric and rheology of co-mingled magmas in the Nasavrky Plutonic Complex (E Bohemia): implications for intrusive strain regime and emplacement mechanism. Tectonophysics 307, 93-111.

Ishibashi, H., Sato, H., 2007. Viscosity measurements of subliquidus magmas: alkali olivine basalt from the Higashi-Matsuura district, Southwest Japan. J. Volcanol. Geotherm. Res. 160, 223-238.

Kadik, A.A., Maksimov, A.P., Ivanov, B.V., 1986. Physico-chemical Conditions for Crystallization of Andesites. Nauka, Moscow. 158 pp. (in Russian).

Kato, H., 1999. Karl Fischer Reagents Technical Manual. Mitsubishi Chemical Corporation, Japan.

Kieffer, S.W., 1981a. Fluid dynamics of the 18 May blast at Mount St. Helens. In: Lipman, P.W., Mullineaux, D.R. (Eds.), The 1980 Eruptions of Mount St. Helens, Washington: U.S. Geol. Surv. Prof. Pap., 1250, pp. 379-401.

Kieffer, S.W., 1981b. Blast dynamics at Mount St. Helens on 18 May 1980. Nature 291, 568-570.

King, P.L., Vennemann, T.W., Holloway, J.R., Hervig, R.L., Lowenstern, J.B., Forneris, J.F., 2002. Analytical techniques for volatiles: a case study using intermediate (andesitic) glasses. Am. Mineral. 87, 1077-1089.

Klug, C., Cashman, K.V., 1994. Vesiculation of May 18, 1980 Mount St. Helens magma. Nature 22, 468-472.

Lavallée, Y., Hess, K.-U., Cordonnier, B., Dingwell, D.B., 2007. Non-Newtonian rheological law for highly crystalline dome lavas. Geology 35, 843-846.

Lipman, P.W., Moore, J.G., Swanson, D.A., 1981. Bulging of the north flank before the May 18 eruption - geodetic data. In: Lipman, P.W., Mullineaux, D.R. (Eds.), The 1980 Eruptions of Mount St. Helens, Washington: U.S. Geol. Surv. Prof. Pap., 1250, pp. $143-155$

Massol, H., Jaupart, C., 2009. Dynamics of magma flow near the vent: implications for dome eruptions. Earth Planet. Sci. Lett. 279, 185-196.

Moore, J.G., Lipman, P.W., Swanson, D.A., Alpha, T.R., 1981. Growth of lava domes in the crater, June 1980-January 1981. In: Lipman, P.W., Mullineaux, D.R. (Eds.), The 1980 Eruptions of Mount St. Helens, Washington: USGS Prof. Pap., 1250, pp. 541-547.

Moore, G., Venneman, T., Carmichael, I.S.E., 1998. An empirical model for the solubility of $\mathrm{H}_{2} \mathrm{O}$ in magmas to 3 kilobars. Am. Mineral. 83, 36-42.

Morgan, G.B.V.I., London, D., 1996. Optimizing the electron microprobe analysis of hydrous alkali aluminosilicate glasses. Am Mineral. 81, 1176-1185.

Nakada, S., Motomura, Y., 1999. Petrology of the 1991-1995 eruption at Unzen: effusion pulsation and groundmass crystallization. J. Volcanol. Geotherm. Res. 89, 173-196.

Navon, O., Chekmir, A., Lyakhovsky, V., 1998. Bubble growth in highly viscous melts: theory, experiments, and autoexplosivity of dome lavas. Earth Planet. Sci. Lett. 160, 763-776.

Newman, S., Epstein, S., Stolper, E., 1988. Water, carbon dioxide, and hydrogen isotopes in glasses from the ca. 1340 A.D. eruption of the Mono craters, California: constraints on degassing phenomena and initial volatile content. J. Volcanol. Geotherm. Res. 35, 75-96. 
Ozerov, A.Yu., Ariskin, A.A., Kyle, P., Bogoyavlenskaya, G.E., Karpenko, S.F., 1997. Petrological-geochemical model for genetic relationships between basaltic and andesitic magmatism of Klyuchevskoi and Bezymiannyi [sic] Volcanoes, Kamchatka. Petrology 5 (6), 614-635.

Pallister, J.S., Thornber, C.R., Cashman, K.V., Clynne, M.A., Lowers, H.A., Brownfield, I.K., Meeker, G.P., 2008. Petrology of the 2004-2006 Mount St. Helens lava dome implications for magmatic plumbing, explosivity and eruption triggering. In: Sherrod, D.R., Scott, W.E., Stauffer, P.H. (Eds.), A Volcano Rekindled: The Renewed Eruption of Mount St. Helens, 2004-2006: U.S. Geol. Surv. Prof. Pap., 1750, pp. 648-702.

Petford, N., 2003. Rheology of granitic magmas during ascent and emplacement. Ann. Rev. Earth Planet. Sci. 31, 399-427.

Pineau, F., Semet, M.P., Grassioneau, N., Okrugin, V.M., Javoy, M., 1999. The genesis of the stable isotope $(\mathrm{O}, \mathrm{H})$ record in arc magmas: the Kamchatka's case. Chem. Geol. 135, 93-124.

Plechov, P.Yu., Tsai, A.E., Shcherbakov, V.D., Dirksen, O.V., 2008. Opacitization conditions of hornblende in Bezymianny [sic] Volcano andesites (March 30, 1956 Eruption). Petrology 16 (1), 19-35.

Proussevitch, A.A., Sahagian, D., 1998. Dynamics and energetics of bubble growth in magmas: analytical formulation and numerical modeling. J. Geophys. Res. 103, 18223-18251.

Ritchie, L., Cole, P., Sparks, R.S.J., 2002. Sedimentology of pyroclastic density current deposits generated by the December 26, 1997 eruption at the Soufrière Hills Volcano, Montserrat. In: Druitt, T., Kokelaar, B.P. (Eds.), The eruption of Soufrière Hills Volcano, Montserrat, from 1995-1999: Mem. Geol. Soc. London, 21, pp. 435-456.

Rutherford, M.J., Hill, P.M., 1993. Magma ascent rates from amphibole breakdown: an experimental study applied to the 1980-86 Mount St. Helens eruptions. J. Geol. Res. 98, 19667-19686.

Rutherford, M.J., Sigurdsson, H., Carey, S.N., Davis, A.J., 1985. The May 18, 1980 eruption of Mount St. Helens 1. Melt composition and experimental phase equilibria. J. Volcanol. Geotherm. Res. 90, 2929-2947.

Schneider, D.J., Vallance, J.W., Wessels, R., Logan, M., Ramsey, M.S., 2008. Use of thermal infrared imaging for monitoring renewed dome growth at Mount St. Helens. In: Sherrod, D.R., Scott, W.E., Stauffer, P.H. (Eds.), A Volcano Rekindled: The Renewed Eruption of Mount St. Helens, 2004-2006: U.S. Geol. Surv. Prof. Pap., 1750, pp. 347-359.

Sharp, Z.D., Atudorei, V., Durakiewicz, T., 2001. A rapid method for determining the hydrogen and oxygen isotope ratios from water and solid hydrous substances. Chem. Geol. 178, 197-210.

Siebert, L., Beget, J.E., Glicken, H.X., 1995. The 1883 and late-prehistoric eruptions of Augustine volcano, Alaska. J. Volcanol. Geotherm. Res. 66, 367-395.

Sparks, R.S.J., Pinkerton, H., 1978. Effect of degassing on rheology of basaltic lava. Nature 276, 385-386.

Spieler, O., Kennedy, B., Kueppers, U., Dingwell, D.B., Scheu, B., Taddeucci, J., 2004. The fragmentation threshold of pyroclastic rocks. Earth Planet. Sci. Lett. 226 (1-2), 139-148.

Stevenson, R.J., Dingwell, D.B., Webb, S.L., Sharp, T.G., 1996. Viscosity of microlitebearing rhyolitic obsidians: an experimental study. Bull. Volcanol. 58, 298-309.
Stewart, A.L., McPhie, J., 2003. Internal structure and emplacement of an Upper Pliocene dacite cryptodome, Milos Island, Greece. J. Volcanol. Geotherm. Res. 124, 129-148.

Swanson, S.E., Naney, M.T., Westrich, H.R., Eichelberger, J.C., 1989. Crystallization history of Obsidian Dome, Inyo Domes, California. Bull. Volcanol. 51, 161-176.

Taylor, B.E., 1986. Magmatic volatiles: isotopic variation of C, H and S. Rev. Mineral Geochem. 16 (1), 185-225.

Taylor, B.E., Eichelberger, J.C., Westrich, H.R., 1983. Hydrogen isotopic evidence of rhyolitic magma degassing during shallow intrusion and eruption. Nature 306, 541-545.

Thomas, N., Jaupart, C., Vergniolle, S., 1994. On the vesicularity of pumice. J. Geophys. Res. 99, 15633-15644.

Toramaru, A., 1995. Numerical study of nucleation and growth of bubbles in viscous magmas. J. Geophys. Res. 100, 1913-1931.

Tuttle, O.F., Bowen, N.L., 1958. Origin of granite in the light of experimental studies in the system $\mathrm{NaAlSi}_{3} \mathrm{O}_{8}-\mathrm{KAlSi}_{3} \mathrm{O}_{8}-\mathrm{SiO}_{2}-\mathrm{H}_{2} \mathrm{O}$. Geo. Soc. Am. Mem., 74. 151 pp.

Vennemann, T.W., O'Neil, J.R., 1993. A simple and inexpensive method of hydrogen isotope and water analyses of minerals and rocks based on zinc reagent. Chem. Geol. 103, 227-234.

Vigneresse, J.L., Tikoff, B., 1999. Strain partitioning during partial melting and crystallizing felsic magmas. Tectonophysics 312, 117-132.

Vigneresse, J.L., Barbey, P., Cuney, M., 1996. Rheological transitions during partial melting and crystallization with application to felsic magma segregation and transfer. J. Petrol. 37 (6), 1579-1600.

Voight, B., 1981. Time scale for the first moments of the May 18 eruption. In: Lipman, P.W. Mullineaux, D.R. (Eds.), The 1980 Eruptions of Mount St. Helens, U.S. Geol. Surv. Prof. Pap., 1250, pp. 69-86.

Voight, B., Glicken, H.X., Janda, R.J., Douglas, P.M., 1981. Catastrophic rockslide avalanche of May 18. In: Lipman, P.W., Mullineaux, D.R. (Eds.), The 1980 Eruptions of Mount St. Helens, Washington: The 1980 Eruptions of Mount St. Helens, U.S Geol. Surv. Prof. Pap., 1250, pp. 347-378.

Voight, B., Esposti Ongaro, T., Widiwidjayanti, C., Neri, A., Clarke, A.B., 2009. New view of lateral blast dynamics at Mount St. Helens. Geol. Soc. Am. 41 (7), 231 Abstracts with Programs.

Wen, S., Nekvasil, H., 1994. SOLVCALC computer program for feldspar thermometry. Comput. Geosci. 20, 1025-1040.

Westrich, H.R., 1987. Determination of water in volcanic glasses by Karl-Fischer titration. Chem. Geol. 163, 335-340.

Westrich, H.R., Stockman, H.W., Eichelberger, J.C., 1988. Degassing of rhyolitic magma during ascent and emplacement. J. Geophys. Res. 93, 6503-6511.

Wright, T.L., Okamura, R.T., 1977. Cooling and crystallization of tholeiitic basalt, 1965 Makaopuhi Lava Lake, Hawaii. U.S. Geol. Surv. Prof. Pap., 1004. 78 pp.

Yu, A.B., Standish, N., 1993. A study of the packing of particles with a mixture size distribution. Powder Technol. 76, 113-124. 